\title{
Neurobiological pathways to Alzheimer's disease Amyloid-beta, TAU protein or both?
}

\author{
Vanessa de Jesus R. de Paula ${ }^{1}$, Fabiana Meira Guimarães ${ }^{1}$, \\ Breno Satler Diniz ${ }^{1}$, Orestes Vicente Forlenza ${ }^{1}$
}

\begin{abstract}
Alzheimer's disease (AD) is a neurodegenerative disease characterized by progressive cognitive decline, including memory loss, behavioral and psychological symptoms and personality changes. The neuropathological hallmarks of $\mathrm{AD}$ are the presence of neuritic (senile) plaques (NP) and neurofibrillary tangles (NFT), along with neuronal loss, dystrophic neurites, and gliosis. Neuritic plaques are extracellular lesions and their main constituent is the amyloid- $\beta_{42}$ peptide $\left(\mathrm{A} \beta_{42}\right)$. Neurofibrillary tangles are intracellular lesions that are mainly composed of hyperphosphorylated TAU protein. In this article, we review the major hypotheses concerning the physiopathology of $\mathrm{AD}$, focusing on the $\beta$-amyloid cascade as primary events (supported by the " $\beta$ aptists") and cytoskeletal abnormalities secondary to the hyperphosphorylation of protein TAU (as advocated by the "Tauists"). We further provide an integrative view of the physiopathology of AD.
\end{abstract}

Key words: TAU protein, amyloid precursor protein, beta amyloid, Alzheimer's disease.

\section{Trajetórias neurobiológicas para a doença de Alzheimer: beta-amilóide, proteína TAU ou ambas?}

Resumo - A doença de Alzheimer (DA) é uma desordem neurodegenerativa progressiva que cursa comprometimento da memória e outras funções cognitivas, alterações comportamentais, psíquicas e da personalidade. Os achados neuropatológicos característicos da DA são as placas neuríticas (senis) e os emaranhados neurofibrilares, também ocorrendo distrofia de neuritos, gliose e perda neuronal. As placas neuríticas são lesões extracelulares que têm no peptídeo beta-amilóide $\left(\mathrm{A} \beta_{42}\right)$ seu principal constituinte. Os emaranhados neurofibrilares são lesões intraneuronais compostas por agregados de proteína TAU em estado hiperfosforilado. Neste artigo de revisão, apresentamos as principais hipóteses relacionadas à fisiopatologia da DA, com foco na cascata do amilóide como evento inicial (hipótese preconizada pelos "ßaptistas") e nas alterações do citoesqueleto neuronal, decorrentes da fosforilação anormal da TAU (conforme proposto pelos “tauístas”). Os achados são discutidos numa leitura integrada desses dois mecanismos fisiopatológicos.

Palavras-chave: TAU, proteína precursora do amilóide, beta-amilóide, doença de Alzheimer.

Alzheimer's disease (AD) is a progressive neurodegenerative disease that accounts for the majority (50 to 75\%) of dementia cases in clinical and population samples. ${ }^{1,2}$ The clinical manifestations of $\mathrm{AD}$ include the progressive deterioration of episodic memory and other intellectual abilities, leading to global cognitive decline, behavioral and psychiatric symptoms and personality changes. Most AD cases begin after 65 years old (i.e. late-onset AD). However, some cases manifest in younger subjects (i.e. early-onset $\mathrm{AD}$ ). The dementia syndrome in these patients usually begins in the $5^{\text {th }}$ or $6^{\text {th }}$ decade of life.
Age and low-educational status are the most important risk factors for late-onset $\mathrm{AD} .{ }^{3}$ Other important risk factors include the presence of the allele $\varepsilon 4$ of the apolipoprotein $\mathrm{E}$ (APOE) gene, history of head trauma with loss of consciousness, life-long uncontrolled cardiovascular risk factors (hypertension, diabetes mellitus, dyslipidemia), sedentary life style, life-long low cognitive demand. ${ }^{4}$ On the other hand, early-onset $\mathrm{AD}$ is usually associated to genetic mutations, the most commonly described being the Amyloid Precursor Protein (APP) gene on chromosome 21, and the Presenilin 1 and 2 genes on chromosomes 14 and 1 , respectively. ${ }^{5}$

${ }^{1}$ Laboratory of Neuroscience LIM-27, Department and Institute of Psychiatry, Faculty of Medicine, University of São Paulo, SP, Brazil.

Orestes Vicente Forlenza - Laboratório de Neurociências / LIM 27 do IP-FMUSP - Rua Dr. Ovídio Pires de Campos 785 / 3 o andar - 05403-010 São Paulo SP. - Brazil. E-mail: forlenza@usp.br

Disclosure: The authors report no conflicts of interest.

Received May 29, 2009. Accepted in final form August 11, 2009. 
Regardless of age of dementia onset, the neuropathological findings in $\mathrm{AD}$ patients are very similar. The hallmarks of $\mathrm{AD}$ are the presence of senile (neuritic) plaques (NP) and neurofibrillary tangles (NFT), together with neuronal loss, dystrophic neurites, and gliosis. ${ }^{6}$ Neuritic plaques are extracellular lesions and their main constituent is the amyloid- $\beta_{42}$ peptide $\left(A \beta_{42}\right)$. Neurofibrillary tangles are intracellular lesions and are mostly composed of hyperphosphorylated TAU protein. Despite controversial findings, the progression of the clinical AD dementia syndrome correlates with the pattern of progression of these lesions in the brain. ${ }^{7}$ In this study, we review the mechanisms involved in the amyloidogenic shift of APP metabolism, along with the cytoskeletal changes that arise from abnormal regulation of TAU phosphorylation. We thus address two major hypotheses in the pathophysiology of $\mathrm{AD}$, namely the $\beta$-amyloid cascade (the " $\beta$ aptists") and the hyperphosphorylation of TAU (the "Tauists").

In order to address the current state of knowledge regarding the role of TAU and amyloid cascade in the pathogenesis of $\mathrm{AD}$, we performed a comprehensive, open review of the literature. We additionally used the key-words "TAU", "amyloid precursor protein", “(beta)-amyloid", "Abeta", "GSK", "Alzheimer's disease” to search the Pubmed and Scielo databases for articles published between 2000 and 2009. Secondary references were also obtained from the reference list of relevant papers, or based on seminal contributions in this field.

\section{The amyloid precursor protein/ amyloid- $\beta$ metabolism and function}

APP is a transmembrane protein and represents one of the most abundant proteins in the central nervous system (CNS). It is also expressed in peripheral tissues, such as epithelium and blood cells. ${ }^{8} \mathrm{APP}$ is alternatively metabolized by two distinct routes, i.e., the non-amyloidogenic and the amyloidogenic pathways. In the former, APP is cleaved by the enzyme $\alpha$-secretase, releasing a soluble $\mathrm{N}$-terminal fragment ( $\mathrm{AAPP} \alpha$ ) and a C-terminal fragment (C83), which is further cleaved by $\gamma$-secretase, releasing a C-terminal fragment of $3 \mathrm{KDa}(\mathrm{C} 3)$. The cleavage of APP by $\alpha$-secretase occurs within the region that contains the $\mathrm{A} \beta$ peptide, precluding the formation of this peptide. ${ }^{9}$ Alternatively, APP may be cleaved by $\beta$-secretase releasing a smaller $\mathrm{N}$-terminal fragment (sAPP $\beta$ ) and a C-terminal fragment (C99) that produces the full-length $\beta$-amyloid peptides $(A \beta)$ upon the subsequent cleavage by $\gamma$-secretase (Figure 1).

There are several $A \beta$ peptide species, where those with 40 and 42 amino acids $\left(A \beta_{40}\right.$ and $\left.A \beta_{42}\right)$ are the most abundant in the brain. ${ }^{10} \mathrm{~A} \beta$ species are released as monomers

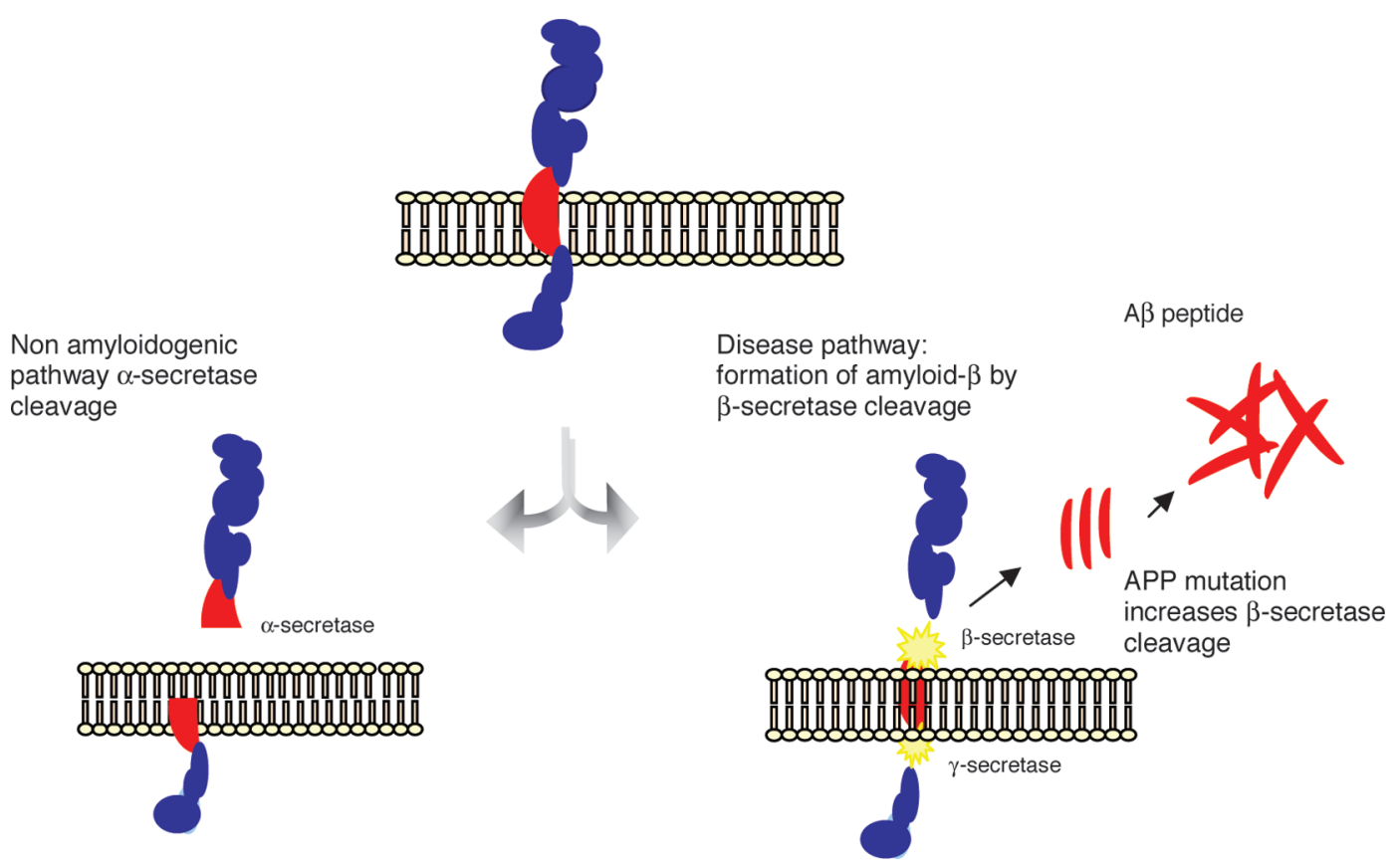

Figure 1. The amyloid precursor protein $(A P P)$ is a transmembrane protein cleaved by secretase enzymes. In the nonamyloidogenic pathway, APP is cleaved preferentially by $\alpha$-secretase. In the amyloidogenic pathway, neurotoxic $A \beta$ peptides are released after sequential cleavage of APP by $\beta$ and $\gamma$-secretases, and further accumulate into oligomeric aggregates. 
which progressively aggregate into dimers, trimers, oligomers, protofibrils and fibrils, to finally deposit and originate diffuse, and then, mature amyloid plaques ${ }^{9}$. Despite their similarities, $A \beta_{42}$ is more prone to aggregation and fibrilization, being the most toxic $\mathrm{A} \beta$ peptide and playing a pivotal role in the pathogenesis of $\mathrm{AD} .{ }^{11}$

The $A \beta$ oligomers are considered the most toxic form of the $\mathrm{A} \beta$ peptide. ${ }^{12}$ They interact with neurons and glial cells leading to the activation of inflammatory cascades, oxidative stress, ${ }^{13}$ deregulation of calcium metabolism and TAU phosphorylation, and induction of neuronal apoptosis. ${ }^{10}$ Together, these phenomena give rise to a self-perpetuating, positive feedback loop in which the production of $A \beta$ peptides leads to deleterious events to the neuronal cells, which in turn contributes to dysfunctional APP metabolism and further production of $A \beta$ peptides. Amyloid- $\beta$ fibrils deposit in neuritic plaques in a sequential pattern: diffuse neuritic plaques, mature neuritic plaques, senile plaques and phantoms of senile plaques in more advanced stages of the disease. The plaque formation also has a deleterious impact on neuronal homeostasis, also leading to dysfunction and, ultimately, neuronal death. ${ }^{14}$

Under physiological conditions, the APP is preferentially metabolized by the non-amyloidogenic pathway and there is equilibrium between the production of $A \beta$ peptides and their clearance from the brain. ${ }^{15}$ Currently, two proteins are deemed as heavily involved in the clearance of $A \beta$ peptides from the brain: apolipoprotein E (APOE) and the insulin degrading enzyme (IDE). The exact mechanism (or mechanisms) by which $\mathrm{A} \beta$ peptides are cleared from the brain has not been established, but a current hypothesis holds that these proteins bind $A \beta$ peptides, inhibiting their aggregation into oligomers and thus facilitating their clearance from brain tissue. ${ }^{13}$ Under pathological conditions, there is a metabolic shift favoring the amyloidogenic cleavage of APP which, along with a reduction of $A \beta$ clearance, leads to the accumulation of $A \beta$ within the brain. ${ }^{16}$

\section{TAU protein metabolism and function}

The TAU protein is a microtubule-associated protein found in most tissues and which is highly expressed in the central and peripheral nervous system. It is an important component of the neuronal cytoskeleton, ${ }^{17}$ given its ability to interact with $\alpha$ - and $\beta$-globulin to stabilize the microtubules $^{18}$ (Figure 2). In neurons, the microtubules are essential for the maintenance of neuronal structure, axonal transport, and synaptic plasticity. ${ }^{19}$

Six TAU isoforms are described in mammals. The main differences between these isoforms hinge on the existence of three or four binding domains to tubulin, in addition to some minor differences in the $\mathrm{N}$-terminal end of the protein. ${ }^{20-23}$ The interaction between TAU and tubulin is a dynamic process in which TAU promotes its own polymerization and inhibits fast depolymerization of the tubulin. ${ }^{24}$ This process is regulated by the phosphorylation state of TAU protein, which comprises approximately 79 phosphorylation sites at serine and threonine residues. ${ }^{25}$ The balance between phosphorylation and dephosphorylation of these epitopes promotes conformational changes that influence how TAU protein interacts with $\alpha$ - and $\beta$-tubulin and that stabilize the microtubules in the neurons. ${ }^{26}$ Several protein kinases and phosphatases are involved in the regulation

\section{Destabilized Microtubules}
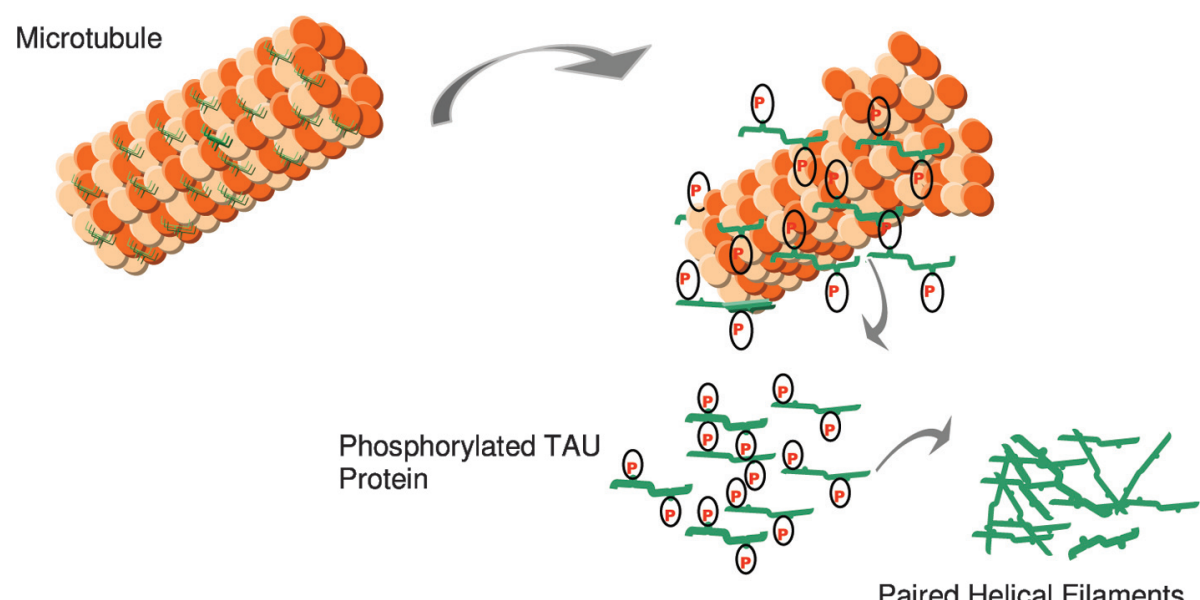

Figure 2. In $A D$, there is a reduction in the ability to bind microtubules and promote microtubule assembly. Hyperphosphorylated Tau may contribute to a destabilized microtubule network, impaired axonal transport, and ultimately in neurofibrillary tangle (NFT) formation and neuronal death. 
of TAU phosphorylation, the enzyme glycogen synthase kinase $3 \beta$ (GSK3 $\beta$ ) being the most important TAU-kinase in the neurons. ${ }^{22}$

A reduction of the expression of certain phosphatases was also identified in cerebral tissues of patients with $\mathrm{AD}$, namely PP1, PP2A and PP5. ${ }^{27}$ The majority of the residues of serine and treonine that are found in a hyperphosphorylated state in fetal TAU and in PHFs is followed by proline, suggesting that TAU kinases belong to the family of proline-directed enzymes, ${ }^{28}$ including cyclin-dependent kinases (CDC2, CDK5, TPK1l), some enzymes of the family of the mithogen-activated kinases (MAPK), and GSK3 $3 .{ }^{29}$ Such enzymes are capable of phosphorylating Tau in vitro and have been detected in the cellular strata of cerebral tissue of individuals with AD. Other non-proline directed kinases have also been identified in neurofibrillary tangles and are important for the regulation of TAU phosphorylation, modulating the activity of the former enzymes. PKC, casein-kinases 1 and $11,{ }^{30}$ calcium calmodulin-kinase 11 (CaMPK-1l), ${ }^{31}$ and protein kinase A (PKA) are examples of this group of enzymes.

At embryonic stages, neuronal TAU is predominantly found in a hyperphosphorylated state. This is due to the great demand for neuroplastic changes in neurons and synapses at early developmental stages of the central nervous system. ${ }^{31}$ On the other hand, in the adult, mature central nervous system, dephosphorylated TAU is required for microtubule stability, necessary for the maintenance of cytoskeletal homeostasis, both at structural and functional levels. ${ }^{22}$ Dynamic changes in the phosphorylation state of TAU occur in mechanisms involved in neuronal remodeling and synaptic plasticity. ${ }^{32}$ Under pathological conditions, including the pathophysiology of AD, TAU can be abnormally hyperphosphorylated, which impairs its capacity to bind to tubulin, leading to destabilization of the microtubule structure ${ }^{33}$ and impairment of axonal transport and synaptic metabolism. Such changes eventually result in the collapse of the cytoskeleton, loss of cellular viability and neuronal death. ${ }^{34}$

\section{The amyloid- $\beta$ cascade hypothesis: the "ßaptist doctrine"}

The amyloid- $\beta$ cascade hypothesis was first described in the early $1990 \mathrm{~s}^{35}$ and a comprehensive review was recently published by Korczyn (2008). ${ }^{36}$ It states that the accumulation of $\beta$-amyloid peptides into neuritic and senile plaques in the brain, due either to their increased production or decreased clearance, is the core pathogenetic feature of $\mathrm{AD}$. The accumulation of $\mathrm{A} \beta$ triggers several neurotoxic events, such as mitochondrial dysfunction, increased oxidative stress, abnormal neuroinflammatory response, ${ }^{13}$ de- creased neurotrophic support, decreased neuroplasticity and neurogenesis, hyperphosphorylation of TAU, apoptosis and disruption of calcium homeostasis. These events occur in a positive feedback loop, amplifying $\mathrm{A} \beta$ neurotoxicity and culminating in neuronal death. ${ }^{13}$ It is not only the accumulation of $A \beta$ which triggers these hazardous events, as the oligomeric and fibrillar forms of the $A \beta$ peptide also interact with neurons and glial cells triggering a series of negative events. In fact, the non-aggregated $A \beta$ forms are currently regarded as the most toxic forms of this protein.

The amyloid- $\beta$ cascade hypothesis was based mostly on in vitro and in vivo studies and was further strengthened by the identification of genetic mutations associated with early-onset AD (e.g. mutation in the APP gene, and presenilin 1 and 2 genes), and the development of genetically modified animal models expressing mutant DNA. ${ }^{5}$ These mutations lead to a massive overproduction of $A \beta$ and subsequent aggregation into oligomers, and deposition in plaques.

There are several open issues regarding the amyloid- $\beta$ cascade hypothesis. First, neuropathological studies found no significant correlation between amyloid plaque density in the brain and severity of dementia. On the other hand, extensive neuronal and synaptic losses are found in the earliest stages of the disease and are better correlated with the cognitive deficits and severity of dementia in these patients. ${ }^{6,36-38} \mathrm{AD}$ is the only neurodegenerative disease in which the $A \beta$ peptide is allegedly the pathological keystone; in contrast, post-mortem studies of the ageing brain show that non-demented individuals may have amyloid plaques similar to those found in $\mathrm{AD}$ patients. ${ }^{39}$ Also, most antiamyloid based therapeutic strategies have failed to show clinically relevant results either in improving cognition or in halting the clinical progression of dementia. ${ }^{40,41}$ Finally, cellular and animal models of AD are based largely on genetic mutations associated with familial, early-onset $A D$ (EOAD), which accounts for a small proportion of dementia cases. Since late-onset AD (LOAD) represents the vast majority of cases, and considering that amyloidogenesis in these patients occurs to a lesser extent compared to the early $\mathrm{AD}$, questions have been raised concerning the appropriateness of EOAD models to aid understanding of LOAD. $^{42}$

\section{TAU protein and Alzheimer's disease ("the Tauists)"}

The intra-neuronal lesions called neurofibrillary tangles $(\mathrm{NFT})^{43}$ were in fact those described by Alois Alzheimer in the beginning of the nineteenth century. The main component of NFTs are the paired helical filaments (PHFs) of hyperphosphorylated TAU (for a review, see Mandelkow et al., 2007). ${ }^{46}$ At least 25 abnormal phosphorylation sites have 
been described in $\mathrm{AD},{ }^{41}$ constituting a marker of neuronal degeneration in this disorder. ${ }^{45}$ The abnormal phosphorylation of TAU in serine/threonine residues near the tubulin binding domain favors disaggregation of the TAU-tubulin complex and the reassembly of TAU into PHFs, giving rise to NFT formation. ${ }^{33}$ Due to the importance of TAU in the maintenance of neuronal stability and homeostasis, its hyperphosphorylation leads to a cascade of events that ultimately cause neuronal death.

There are several lines of evidence that support the notion that the dysfunction in TAU homeostasis is a primary event in $\mathrm{AD}$, a phenomenon also found in other neurodegenerative disorders, such as frontotemporal dementia (Pick's disease) and multiple system atrophy. ${ }^{33}$ Neuropathological studies have shown that the distribution of NFTs in the brain correlates with the clinical progression of dementia in $\mathrm{AD}^{7}$ Moreover, intra-neuronal hyperphosphorylated TAU can be found in brain of subjects with very mild dementia, unaccompanied by $\beta$-amyloid pathology. ${ }^{45,47,48}$ Therefore, TAU hyperphosphorylation may be an early event in the physiopathology of $\mathrm{AD}$, whereas other pathological mechanisms, including $\mathrm{A} \beta$ overproduction and activation of inflammatory cascades and oxidative stress, may be secondary to the overall dysfunction in neuronal homeostasis. ${ }^{39}$ However, the larger body of evidence linking amyloid- $\beta$ to $\mathrm{AD}$, along with the lack of genetic mutations in the TAU gene associated to early or late-onset $\mathrm{AD}$, weaken the hypothesis that abnormalities in TAU may be the trigger of other pathologic events in $\mathrm{AD} .^{13}$

\section{The GSK3 3 hypothesis}

Despite the strong evidence supporting the primary role of $A \beta$ peptides and hyperphosphorylated TAU in the pathogenesis of $\mathrm{AD}$, neither hypothesis satisfactorily accounts for the full spectrum of pathological processes associated with this disease. In addition, alternative hypotheses suggest that NFTs and A $\beta$ plaques may be independent epiphenomena in the course of AD. ${ }^{6,38}$ Therefore, alternative mechanisms have been proposed, most of which involve the activity of upstream enzymes that play a role in these two cascades. GSK3 $\beta$ is a key enzyme in the regulation of cellular metabolism including TAU phosphorylation. Wnt signaling may represent another important aspect in the neurobiology of $\mathrm{AD}$, since Wnt signaling leads to the inactivation of GSK, preventing TAU phosphorylation in the GSK-dependent epitopes. ${ }^{49,50}$ In AD, GSK3 $\beta$ has been found in a hyperactive state, leading to hyperphosphorylation of TAU. Recent studies have also demonstrated that GSK3 $\beta$ also regulates APP metabolism, and is conducive to amyloidogenic cleavage (and thus the overproduction of $A \beta$ ), reduced neurogenesis and increased apoptosis. ${ }^{46}$
In vitro studies have shown that the pharmacological activation of GSK3 $\beta$ leads to neuronal changes and death in a similar fashion to that observed in $\mathrm{AD}^{50,53}$ On the other hand, in vitro and in vivo studies have demonstrated that the pharmacological inhibition of GSK3 $\beta$ activity (e.g. with lithium salts) protects against neuronal degeneration and death induced by $\mathrm{A} \beta$ and Tau hyperphosphorylation. ${ }^{50-54}$ Few studies have been carried out in humans to determine the activity of GSK3 $\beta$ in $A D$ patients. One interesting study in human leukocytes showed that peripheral GSK3 $\beta$ activity is increased in $\mathrm{AD} .{ }^{55}$ Such converging evidence support the "GSK3 $\beta$ hypothesis" in $\mathrm{AD},{ }^{56}$ according to which, the deregulation of GSK3 $\beta$ metabolism leading to increased activity is an early pathological event in the pathophysiology of $\mathrm{AD}$, triggering several downstream events culminating in increased production of $A \beta$ and TAU hyperphosphorylation. Despite the elegant mechanisms elicited by the GSK3 $\beta$ hypothesis, which encompasses in a broader sense both "ßaptists" and "Tauists", it lacks consistent empirical evidence to go beyond the prevailing hypotheses.

\section{Conclusions}

Alzheimer's disease is a complex neurodegenerative disease with a multi-factorial etiology. Current hypotheses, namely the amyloid cascade and TAU pathology, only partially explain the pathophysiology of the disease. It is likely that no single hypothesis will be able to account for all the aspects that underlie the disease process, or to differentiate pathological from normal brain ageing. Given the evidence reviewed in the present study, amyloid deposition and production and/or tau hyperphosphorylation in the brain could be an epiphenomena in the course of AD and not the mainstream features of its pathogenesis. ${ }^{36,37} \mathrm{New}$ concepts such as brain and cognitive reserve, neuroplasticity, neurogenesis, restorative functions and neuronal resilience to chronic insults, should be explored to better understand the physiopathology of this complex disorder.

\section{References}

1. Herrera E Jr, Caramelli P, Silveira AS, Nitrini R. Epidemiologic survey of dementia in a community-dwelling Brazilian population. Alzheimer Dis Assoc Disord 2002;16:103-108.

2. Nitrini R, Caramelli P, Herrera E Jr, et al. Incidence of dementia in a community-dwelling Brazilian population. Alzheimer Dis Assoc Disord 2004;18:241-246.

3. Hestad K, Kveberg B, Engedal K. Low blood pressure is a better predictor of cognitive deficits than the apolipoprotein e4 allele in the oldest old. Acta Neurol Scand 2005;111:323-328.

4. Ravona SR, Davidson M, Noy S. The role of cardiovascular risk factors in Alzheimer's disease. CNS Spectr 2003;8:824-833.

5. Boeras DI, Granic A, Padmanabhan J, Crespo NC, Rojiani AM, 
Potter H. Alzheimer's presenilin 1 causes chromosome missegregation and aneuploidy. Neurobiol Aging 2008;29:319-328.

6. Castellani RJ, Lee HG, Zhu XW, Nunomura A, Perry G, Smith MA. Neuropathology of Alzheimer disease: pathognomonic but not pathogenic, Acta Neuropathol 2006;111: 503-509.

7. Braak H, Braak E. Neuropathological stageing of Alzheimerrelated changes. Acta Neuropathol 1991;82:239-259.

8. Di Luca M, Colciaghi F, Pastorino L, Borroni B, Padovani A, Cattabeni F. Platelets as a peripheral district where to study pathogenetic mechanisms of alzheimer disease: the case of amyloid precursor protein. Eur J Pharmacol 2000;405:277-283.

9. Roberts GW, Gentleman SM, Lynch A, Murray L, Landon M, Graham DI. Beta amyloid protein deposition in the brain after severe head injury: implications for the pathogenesis of Alzheimer's disease. J Neurol Neurosurg Psychiatry 1994;57: 419-425.

10. Korczyn AD. The amyloid cascade hypothesis. Alzheimers Dement 2008;4:176-178.

11. Kontush A. Apolipoprotein Abeta: black sheep in a good family. Brain Pathol 2004;14:433-447.

12. Sanz-Blasco S, Valero RA, Rodríguez-Crespo I, Villalobos C, Núñez L. Mitochondrial Ca2+ overload underlies Abeta oligomers neurotoxicity providing an unexpected mechanism of neuroprotection by NSAIDs. PLoS ONE 2008;23:2718.

13. Rhein V, Eckert A. Effects of Alzheimer's amyloid-beta and tau protein on mitochondrial function: role of glucose metabolism and insulin signaling. Arch Physiol Biochem. 2007; 113:131-141.

14. Oide T, Kinoshita T, Arima K. Regression stage senile plaques in the natural course of Alzheimer's disease. Neuropathol Appl Neurobiol 2006;32:539-556.

15. Vetrivel KS, Thinakaran G. Amyloidogenic processing of $\beta$-amyloid precursor protein in intracellular compartments. Neurology 2006;66(2 Suppl 1):S69-S73.

16. Kunjathoor VV, Tseng AA, Medeiros LA, Khan T, Moore KJ. $\beta$-Amyloid promotes accumulation of lipid peroxides by inhibiting CD36-mediated clearance of oxidized lipoproteins. J Neuroinflammation 2004;16:23.

17. Kosik KS. The molecular and cellular biology for tau. Brain Path 1993;3:39-43.

18. Lindwall G, Cole RD. Phosphorylation affects the ability of tau protein to promote microtubule assembly. J Biol Chem 1984;259:5301-5305.

19. Cleveland DW, Hoffman PN. Neuronal and glial cytoskeletons. Curr Opin Neurobiol 1991;1:346-353.

20. Lovestone S, Anderton B. Cytoskeletal abnormalities in Alzheimer's disease. Curr Opin Neurol Neurosurg 1992;5:883-888.

21. Trojanowski JQ, Lee VM. Paired helical filament tau in Alzheimer's disease. The kinase connection: neurobiology of Alzheimer's disease. Am J Pathol 1994;144:449-453.

22. Lovestone S, Reynolds CH, Latimer D, et al. Alzheimer's disease-like phosphorylation of the microtubule-associated protein tau by glycogen synthase kinase- 3 in transfected mammalian cells. Curr Biol 1994;4:1077-1086.

23. Shahani N, Brandt R. Functions and malfunctions of the tau proteins. Cell Mol Life Sci 2002;39:1668-1680.

24. Drechsel DN, Hyman AA, Cobb MH, Kirschner MW. Modulation of the dynamic instability of tubulin assembly by the microtubule-associated protein tau. Mol Biol Cell 1992; 3: 1141-1154.

25. Hernández F, Avila J. Tauopathies. Cell Mol Life Sci 2007;64: 2219-2233.

26. Buée L, Bussière T, Buée-Scherrer V, Delacourte A, Hof PR. Tau protein isoforms, phosphorylation and role in neurodegenerative disorders. Brain Rev Brain Res 2000; 33:95-130.

27. Wang JZ, Grundke-Iqbal I, Iqbal K. Kinases and phosphatases and tau sites involved in Alzheimer neurofibrillary degeneration. Eur J Neurosci 2007;25:59-68.

28. Vuillet J, Dimova R, Nieoullon A, Kerkerian-Le Goff L. Ultrastructural relationships between choline acetyltransferaseand neuropeptide $y$-containing neurons in the rat striatum. Neuroscience 1992;46:351-360.

29. Anderton BH, Betts J, Blackstock WP, et al. Sites of phosphorylation in tau and factors affecting their regulation. Biochem Soc Symp. 2001;(67):73-80.

30. Lovestone S, Hartley CL, Pearce J, Anderton BH. The phosphorylation of Tau: a critical stage in neurodevelopmental and neurodegenerative processes. Neuroscience 1997; 78:309-324.

31. Ribaut-Barassin C, Dupont JL, Haeberlé AM, et al. Alzheimer's disease proteins in cerebellar and hippocampal synapses during postnatal development and aging of the rat. Neuroscience 2003;120:405-423

32. Iqbal K, Adel C, Chen S, et al. Tau pathology in Alzheimer disease and other tauopathies. Biochem Biophys Acta 2005;13: 198-210.

33. Johnson GV, Stoothoff WH. Tau phosphorylation in neuronal cell function and dysfunction. J Cell Sci 2004;117(Pt 24): 5721-5729.

34. Fasulo L, Ugolini G, Visintin M, et al. Cattaneo A The neuronal microtubule-associated protein tau is a substrate for caspase-3 and an effector of apoptosis. J Neurochem 2000; 75:624-633

35. Hardy JA, Higgins GA. Alzheimer's disease: the amyloid cascade hypothesis. Science 1992;256(5054):184-185.

36. Duyckaerts C, Delatour B, Potier MC. Classification and basic pathology of Alzheimer disease. Acta Neuropathol 2009;118-36.

37. Schmitt HP. Neuro-modulation, aminergic neuro-disinhibition and neuro-degeneration. Draft of a comprehensive theory for Alzheimer disease. Med Hypotheses 2005;65: 1106-1119.

38. Zhu X, Avila J, Perry G, Smith MA, Treating the lesions not the disease. Am J Pathol 2007;170:1457-1459.

39. Selkoe DJ. Amyloid protein and Alzheimer's disease. Sci Am 1991;265:68-71. 
40. Lippa CF, Morris JC. Alzheimer neuropathology in nondemented aging: keeping mind over matter. Neurology 2006;66: 1801-1802.

41. Cummings J. Challenges to demonstrating disease-modifying effects in Alzheimer's disease clinical trials. Alzheimer Dement 2006;2:263-271.

42. Holmes C, Boche D, Wilkinson D, et al. Long-term effects of A $\beta 42$ immunization in Alzheimer's disease: follow-up of a randomised, placebo-controlled phase I trial. Lancet 2008; 372:216-223.

43. Swerdlow RH. Pathogenesis of Alzheimer's disease. Clin Interv Aging. 2007;2:347-359.

44. Braak H, Tredici KD. Alzheimer's disease: intraneuronal alterations precede insoluble amyloid- $\beta$ formation. Neurobiol Aging 2004;25:713-718.

45. Mazanetz MP, Fischer PM. Untangling tau hyperphosphorylation in drug design for neurodegenerative diseases. Nat Rev Drug Discov 2007;6:464-479.

46. Mandelkow E, von Bergen M, Biernat J, Mandelkow EM.. Structural principles of tau and the paired helical filaments of Alzheimer's disease. Brain Pathol 2007;17:83-90

47. Yilmazer-Hanke DM, Hanke J. Progression of Alzheimer-related neuritic plaque pathology in the entorhinal region, perirhinal cortex and hippocampal formation. Dement Geriatr Cogn Disord 1999;10:70-76.

48. Grinberg LT, Rüb U, Ferretti RE, et al. Brazilian Brain Bank Study Group. The dorsal raphe nucleus shows phospho-tau neurofibrillary changes before the transentorhinal region in
Alzheimer's disease. A precocious onset? Neuropathol Appl Neurobiol 2009;35:406-416.

49. Bhat RV, Budd SL. GSK3beta signaling: casting a wide net in Alzheimer's disease. Neurosignals 2002;11:251-261.

50. Boonen RA, van Tijn P, Zivkovic D. Wnt signaling in Alzheimer's disease: up or down, that is the question. Ageing Res Rev 2009;8:71-82.

51. Wang Y, Zhang JX, Du XX, et al. Temporal correlation of the memory deficit with Alzheimer-like lesions induced by activation of glycogen synthase kinase-3. J Neurochem 2008;106:2364-2374.

52. Forlenza OV, Spink JM, Dayanandan R, Anderton BH, Olesen OF, Lovestone S. Muscarinic agonists reduce tau phosphorylation in non-neuronal cells via GSK-3 $\beta$ inhibition and in neurons. J Neural Transm 2000;107:1201-1212.

53. Noble W, Planel E, Zehr C, et al. Inhibition of glycogen synthase kinase- 3 by lithium correlates with reduced tauopathy and degeneration in vivo. Proc Natl Acad Sci USA. 2005;102: 6990-6995.

54. Mendes CT, Mury FB, de Sá Moreira E, et al. Lithium reduces Gsk3b mRNA levels: implications for Alzheimer Disease. Eur Arch Psychiatry Clin Neurosci 2009;259:16-22.

55. Hye A, Kerr F, Archer N, et al. Glycogen synthase kinase-3 is increased in white cells early in Alzheimer's disease. Neurosci Lett 2005;373:1-4.

56. Hooper PL. Insulin Signaling, GSK-3, Heat Shock Proteins and the Natural History of Type 2 Diabetes Mellitus: A Hypothesis. Metab Syndr Relat Disord. 2007;5:220-230. 